\title{
A Comparative Study of a Restitutionary Remedy for an Undue Influence between the English Law and the Islamic Legal Principles
}

\author{
Md. Nannu Mian ${ }^{1}$, Shalina Akter ${ }^{2}$
}

\begin{abstract}
In practice, an undue influence is an exceptional phenomenon in a transaction; however, the remedy for an undue influence is a very pertinent issue in every transaction. In the modern world, the forms of undue influence are very complex, thus, the types of remedy for this influence also vary from one transaction to another transaction under the Common Law Legal System. In this type of situation, a restitutionary remedy could be more appropriate rather than damage or a compensation for the claimant in a transaction, but in many cases the court usually refuses to grant a restitution resulting from an undue influence due to an ambiguity of the laws. As a result, the claimant is sometimes not provided with an adequate legal remedy for a possible unjust enrichment of the defendant as appropriate for the circumstance. On the other hand, a restitutionary right for an undue influence is also recognized in the Islamic law. According to the Islamic Legal Principles, an influencer is bound to restore the subject matter of the contract made under an undue influence. The focus of the research will be a restitutionary remedy for an undue influence exercised by the defendant at the expense of the plaintiff.
\end{abstract}

Keywords: Restitution, Unjust Enrichment, Remedy, Undue Influence, Islamic Legal Principles.

Submitted Date 17 June 2013

Accepted Date: 22 June 2013

\section{Introduction}

The law of restitution is to be contrasted with the law of compensation. The law of compensation is regarded as a legal remedy; whereas the law of restitution is regarded as an equitable remedy. ${ }^{1}$ Obligations to make a restitution and obligations to pay a compensation are each a type of legal response to events in the real world. When a court orders a compensation, it orders the defendant to compensate the claimant for the loss. ${ }^{2}$ However, when a court orders a restitution, it orders the defendant to give up the gains to the claimant because the defendant was unjustly enriched at the expense of the plaintiff. The basic principle of restitution is the avoidance of an unjust enrichment of the defendant at the expense of the plaintiff. ${ }^{3}$ Where the plaintiff has mistakenly bestowed an actual benefit on the defendant, a corrective justice demands that it be returned to the plaintiff unless there are some good juristic reasons to bar the restitution. A restitution is also sought where the plaintiff has not in fact conferred a benefit on the defendant but has been deprived of the opportunity of exercising a right or where the defendant has profited from a wrongdoing, for instance, from an undue influence and arguably this profit is made at the plaintiff's expense and it is not justifiable under the law for the defendant to enjoy the profit. This is commonly referred to as a restitution of profits arising from a wrongdoing by the defendant. ${ }^{4}$

Restitutionary remedies are very significant in any transaction where, one of the parties may be unduly influenced by the other party to transfer the money or property. Consequently, the influenced party may be affected by that unfair and improper transaction. On the other hand, the other party who is in the position to exercise an undue influence and in fact the person (the defendant) has exercised an undue influence and has gained an undue advantage over the other party (the plaintiff). In that circumstance, the affected party may claim a restitution of unjust gains made by the defendant who has exercised an undue influence instead of claiming damages. ${ }^{5}$ The reason might be that a restitutionary claim would be better for the plaintiff to prove the case, for instance, the unjust advantage gained by the defendant due to the undue influence instead of proving a loss. Whether the plaintiff will be able to pursue with the restitutionary claim is an objective test and it solely depends on a case by case basis.

In the case of an undue influence in a transaction, usually the plaintiff claims a compensation from the dependant and this is the general practice in law. ${ }^{6}$ However, there are exceptional situations where the plaintiff

\footnotetext{
${ }^{1}$ Department of Law, Uttara University, Bangladesh

${ }^{2}$ Department of Law, Uttara University, Bangladesh
} 
may apply to the competent court for a restitution of money or property given under an undue influence instead of claiming a compensation for the loss suffered. This usually happens when the plaintiff finds difficulty to prove the loss or the amount of loss is insignificant but the defendant has made a handsome amount of profit by exercising an undue influence in a transaction at the expense of the plaintiff and enjoys such profit by the defendant who is liable for an unjust enrichment. ${ }^{7}$ Such situation arose in some cases in the United Kingdom, Australia and some other countries, for instance, in Jayne Hewett v First Plus Financial Group Plc ${ }^{8}$, Mrs Joyce $^{2}$ De Wind v Mr Colin Wedge, ${ }^{9}$ Euroasia (Pacific) Pty Ltd v Michael $^{10}$ and Allcard v Skinner. ${ }^{11}$ In these cases, the court was careful to point out that the normal legal response to an undue influence in a transaction is to award a compensation. An order to make a restitution was said to be available only in exceptional circumstances. Therefore, in many cases, the court usually refuses to grant a restitution instead of a compensation for an undue influence in the transaction. Therefore, the research undertakes the difficult task of exploring exceptional circumstances under which a restitution rather than a compensation can be claimed. The research will also focus on a restitutionary claim in a transaction where one of the parties had paid some advance money in a transaction which was caused by an undue influence and later the person repudiates the transaction to claim a restitution of the money paid.

\section{Remedy under English law}

An undue influence is an equitable ground of restitution which applies where the defendant is in a relationship of influence over the plaintiff and the defendant either abuses that relationship to persuade the plaintiff to transfer a benefit to him, or he is presumed to have abused that relationship to induce the transfer of a benefit. There are consequently two forms of undue influence, namely, i) actual and ii) presumed. Both types of undue influence may be applicable in one case and both of them can be pleaded in the same case. ${ }^{12}$

An undue influence constitutes a ground of restitution because the effect of the actual or presumed abuse of the defendant's relationship with the plaintiff is that the plaintiff's decision to transact with the defendant cannot be regarded as freely exercised. This was expressed by Eldon LC in Huguenin v Baseley, ${ }^{13}$ who said that the question was not whether the plaintiff knew what she was doing, had done, or proposed to do, but how the intention was produced. Consequently, where the plaintiff has been induced to transact with the defendant by an actual or a presumed undue influence, his or her intention to enter into the transaction can be regarded as vitiated. The policy behind an undue influence as a ground of restitution is to protect the vulnerable from an exploitation by those who are in a stronger position than those under the undue influence, rather than a policy to set aside transactions on the ground of the plaintiff's folly, imprudence or lack of foresight. ${ }^{14}$

By far the most controversial and practically important question relating to the role of an undue influence as a ground of restitution arises where the plaintiff has entered into a transaction with the defendant as a result of an undue influence from a third party. ${ }^{15}$ In such circumstances, the plaintiff's weakness is exploited by the third party and it is necessary to determine which of the two innocent parties, the plaintiff or the defendant, should suffer from this exploitation. The undue influence, whether plaintiff or defendant oriented, is a ground of restitution, because the effect of the actual or presumed abuse of the defendant's relationship of influence with the plaintiff is that the plaintiff's decision to transact with the defendant cannot be regarded as freely exercised. In fact, an undue influence is one of the grounds of restitution of money or property in a transaction and the complainant is entitled to get back the money or property which was obtained and retained by the defendant under an undue influence. Moreover, if a third party creates an undue influence to the claimant to enter into a transaction with the defendant, the claimant will also be entitled to get back the money or property which he has transferred to the defendant during the transaction.

An undue influence is an equitable wrong. He who exercises an actual undue influence, such as he who exercises specific acts of persuasion over another, has undoubtedly acted in a bad faith. ${ }^{16}$ However, an undue influence may be presumed from the relationship between the parties, even though the person exercising it acts in a perfectly good faith. For that reason in Pesticcio v Huet, ${ }^{17}$ Mummery L.J. emphasized that, although an undue influence was sometimes described as an equitable wrong or even as a species of equitable fraud, the basis of the court's intervention was not the commission of a dishonest or wrongful act by the defendant, but that, as a matter of policy, the presumed influence arising from the relationship of trust and confidence should not operate to the disadvantage of the victim, if the transaction was not satisfactorily explained by ordinary motives. ${ }^{18}$ The court scrutinizes the circumstances in which the transaction, under which benefits were conferred on the recipient, took place and the nature of the continuing relationship between the parties, rather than any specific act of conduct on the part of the recipient. A transaction may be set aside by the court, even though the actions and conduct of the person who benefits from it cannot be criticized as wrongful.

If an actual undue influence is alleged, it is necessary for the plaintiff to prove affirmatively that the defendant has exerted an undue influence on the plaintiff to enter into the particular transaction which is impugned. In the view of the Court of Appeal in BCCI v Aboody ${ }^{19}$ a person relying on a plea of actual undue influence must show that; (a) the other party to the transaction (or someone who induced the transaction for his 
own benefit) had the capacity to influence the complainant; (b) the influence was exercised; (c) its exercise was undue; (d) its exercise brought about the transaction. For its exercise to amount to an undue influence, the party relying on the plea must show specific (or overt) acts of persuasion. In National Westminster Bank plc $v$ Morgan ${ }^{20}$ which was a case of a presumed undue influence, the House of Lords had held that a transaction would be set aside on that ground only if the transaction was to the manifest disadvantage of the person influenced. The Court of Appeal subsequently concluded, in BCCIv Aboody, ${ }^{21}$ that a person who was the victim of an actual undue influence should also demonstrate that a transaction was manifestly disadvantageous. However, in CIBC Mortgages plc v Pitt, ${ }^{22}$ the House of Lords overruled Aboody on this point.

The presumption of an undue influence has been customary for the English law to identify certain relationships where an undue influence can be drawn so easily as to establish a presumption of an undue influence. However, this is simply a matter of evidence and proof. The general principle is that he who asserts that a wrong has been committed must prove it. The burden of proof is normally on the person who asserts that he was induced to enter into the transaction because of another's misrepresentation or his exercise of an undue influence. This burden is prima facie discharged if the complainant can demonstrate that there was a relationship of trust and confidence and a transaction, which calls for an explanation. The evidential burden then shifts to the other party who must produce an evidence to counter the inference which would otherwise be drawn. The use of the term presumption is descriptive of a shift in the evidential onus on a question of fact. The cases where an undue influence is presumed, in this sense, are the equitable counterpart of common law cases where the principle of res ipsa loquitur is invoked. There are certain relationships where the law unquestionably presumes an undue influence. If the complainant, who is vulnerable and dependent, has made a substantial gift, the other party must then demonstrate that he has acted fairly to the complainant and that there are good reasons why the complainant has entered into the transaction. It is not conclusive that the Donee can demonstrate that the complainant received an independent advice or that the Donee's conduct was unimpeachable.

The victim of an undue influence may rescind a transaction which has been so induced. In equity, the victim has the right to rescind the transaction. If the transaction is rescinded then the title to the property transferred to the defendant must be returned to the victim if the property is identifiable. The victim cannot rescind it if he cannot restore the status quo ante. Such will be the case if third party rights have intervened before any court order is made.

Any transactions made with an undue influence will be voidable and may be revoked at the election of the claimant against the influencer or any party who has noticed the transaction, actual or constructive. ${ }^{23} \mathrm{An}$ undue influence is concerned with closer relationships and dependency, such as, physical, emotional and sexual. Where an expressed undue influence is demonstrated, the transaction will be set aside as between the influencer and the claimant and there must be a restitution of any benefits rendered ${ }^{24}$ Where a legal or factual presumption of an undue influence arises, the burden of proof shifts to the influencer to prove that the complainant has entered into the transaction with a full, free and informed thought. If the influencer cannot discharge this onus of proof, the rescission follows.

A transaction or contract made under an undue influence is vitiated. An undue influence is arisen from an unfair or improper conduct, some coercion from outside, some overreaching, some form of cheating, and generally, though not always, some personal advantages obtained by a Donee placed in some close and confidential relationship to the donor. ${ }^{25}$ Some such cases are properly cases of duress, for example, Williams $v$ Bayley, ${ }^{26}$ was a case of duress, but was decided as a case of an undue influence. An undue influence is now understood to arise where the plaintiff comes under the influence of the defendant or a third party to the extent of surrendering his independence of mind. A distinction is made between cases of an actual and presumed undue influence.

In a case of an actual undue influence, the plaintiff proves that the stronger party in the relationship actually exercised his influence over him with respect to the particular transaction in issue. In the case of a presumed undue influence, it is presumed that such influence was exercised because of the nature of the relationship between the two parties. The presumption is automatically made with respect to certain recognized categories of relationship, where the relationship is thought inevitably to subject the plaintiff to the risk of an undue influence.

The presumption can also be made if the plaintiff shows that, although the relationship in question does not fall within such a category, it is nevertheless such as to justify a presumption. The relationships that have been held to attract the presumption automatically include parent and child, superior and member of a sisterhood, doctor and patient, and solicitor and client. In Barclays Bank v O'Brien, ${ }^{27}$ the nature of the relationship between the husband and wife in that case was found to be such as to justify the presumption, even though the category of husband and wife relationships does not automatically attract it. 


\section{Remedy under Islamic legal principles}

A restitutionary right for an undue influence is also recognized in the Islamic law. A restitution based on an unjust enrichment by an undue influence has never been a matter of dispute in the Islamic legal system. However, the idea of a restitution resulting from an undue influence has been introduced indirectly in the Qur'an and the Hadith. The Qur'an states that "Eat not up your property among yourselves unjustly except it is a trade amongst you, by mutual consent ${ }^{\text {"28 }}$ which means a person is entitled to eat or hold any property through a mutual transaction or contract but not through an undue influence, misrepresentation, fraud, duress and others. A person is not permitted to consume or hold any property which is obtained under an undue influence or other illegal means. Besides, the Qur'an states that "Whoever commits that through aggression and injustice, We shall cast him into the fire, and that is easy for Allah" ${ }^{29}$ which clearly describes that if any person consumes or holds any property obtained through an undue influence or other illegal means, except legal business, he has to face a great punishment in hell.

This general principle is also restated in the Majallah referring to the property which states that if it is taken without a justifiable cause, it must be restored regardless of whether it is taken by theft, undue influence, prank or error. ${ }^{30}$ On the basis of this precept, jurists have laid down the principle of restitution. The Islamic law guarantees property rights of an individual, including orphan, and nobody should be deprived of his possession, save in accordance with the law. It is illegal to deal in the property of others without a lawful permission or trusteeship. This principle derives its legitimacy from the Qur'an and the Hadith of the Prophet Mohammad (S). The Qur'an says "Give unto orphans their property and do not exchange (your) bad things for (their) good ones; and devour not their substance (by adding it) to your substance. Surely, this is a great $\sin .{ }^{, 31}$ This particular passage means that Allah commands that the property of the orphans be surrendered to them in full and not to change the goods with the orphan's goods and not to devour the orphan's property illegally. If any body does not return an orphans' property in full and consumes or holds it by any illegal ways, such as undue influence, misrepresentation and others, he has to face a great punishment.

Furthermore, the Qur'an says "Try orphans (as regards their intelligence) until they reach the age of marriage; if then you find sound judgment in them, release their property to them, but consume it not wastefully, and hastily fearing that they should grow up, and whoever amongst the guardians is rich, he should take no wages, but if he is poor, let him have for himself what is just and reasonable (according to his work). Furthermore, when you release their property to them, take witness in their presence" 32 and "Verily, those who unjustly eat up the property of orphans, they eat up only a fire into their bellies, and they will be burnt in the blazing Fire! ${ }^{33}$ which means poor caretakers are allowed to wisely spend from the money of the orphan under their care, to compensate for their work, while on the other hand, a rich caretaker is not allowed to take wages from the orphans' property. Besides, Allah commands the guardians of orphans to surrender the property of the orphans who become consenting adults, in the presence of a witness, so that none of them denies the fact that he receives his money. The Qur'an also says that Allah is sufficient as a witness. Therefore, nobody is allowed to consume or hold the property of orphans by exercising an undue influence, misrepresentation, fraud and other illegal means. In addition, the Qur'an says that those who hold or consume the property of orphans illegally will be thrown into the fire.

The Qur'an says, that "you seek them (women who are not forbidden) in marriage with the mahr (obligatory bridal money given by the husband to his wife at the time of marriage) from your property, desiring chastity, not committing illegal sexual intercourse, so with those of whom you have enjoyed sexual relations, give them their mahr as prescribed; but if after a mahr is prescribed, you agree mutually (to give more), there is no sin on you. Surely, Allah is Ever All-Knowing, All-Wise." ${ }^{\prime 34}$ According to the statement, the husband is bound to give a mahr (an obligatory bridal money given by the husband to his wife at the time of marriage) to his wife and this is obligatory in the Islami law. Besides, marriage is a civil contract and both parties (husband and wife) are bound to fulfil the conditions of the contract. However, in practice, the husband does not give the full mahr to his wife in many countries, such as, Bangladesh, India, Malaysia, Indonesia and others. Sometimes the husband does not give the mahr at all. This is definitely a relational undue influence exercised by the husband over his wife. Despite the right of the mahr, the wife cannot claim it from her husband due to the close marital relationship.

The Qur'an also says that "if you marry any captive or slave girl, take permission from her guardian or master and give a reasonable mahr as it is obligatory", ${ }^{35}$ which proves that the mahr is compulsory and the husband is bound to give. Otherwise it is a great sin and if the husband does not give the mahr, he has to face a divine punishment. The Qur'an also says "if you intend to replace a wife by another and you have given one of them a Cantar (of gold i.e. a great amount) as the Mahr, take not the least bit of it back", ${ }^{36}$ which proves that only the wife has the right on the mahr and the husband has no right on the mahr of his wife and the wife can use it as per her own desire. However, in practice, the husband makes an undue influence upon his wife to use the mahr as per the desire of him. In this case, the wife can claim a restitution of her mahr. 
The Qur'an states not to take one another's property unjustly ${ }^{37}$ and it also commands on the share of inheritance of a male and a female which is "one male will get a portion equal to that of two females; if (there are) only daughters, two or more, their share is two thirds of the inheritance; if only one, her share is half. ${ }^{38}$ According to the statements, the Qur'an has clearly mentioned that nobody is entitled to take or hold another's property unjustly and if anybody does it, he will be punished. Besides, Allah has clearly mentioned on the share of inheritance for both the male and the female. In practice, we see that after the death of a father or a mother, the son wants to possess the entire property of his father or mother. Moreover, the son (male) practices an undue influence over his sister (female) and takes the property for a very less price. Sometimes the brother does not give any money at all to his sister and takes the property by exercising an undue influence. By practising a relational undue influence, the brother takes the property at the expense of the sister and this is a very common practice in the society. Therefore, the female has the right to claim the restitution of the property from his brother, which was obtained under an undue influence.

The Islamic law principles provide that, if the property which was obtained under an undue influence or any other illegal ways, is in existence, there should be a complete restoration of the actual entity which should be restitutionary by the court's order. If it has been destroyed, the remedial order proceeds to restore the property to the same value and equivalence. ${ }^{39}$

All schools of the Islamic law are unanimous upon the issue that, if the property which was transferred under an undue influence is extant and is in the possession of the influencer, and there has been no improvement or decay in the said property, it is the duty of the influencer to restore the property to the rightful owner. In such case, the Islamic law provides no other alternative but for the restitution of the original entity. According to Shaffi, in mithill property cases, the highest price should be paid by measuring the value of the property from the date of usurpation till the date when the property was lost, destroyed or otherwise changed its original condition. According to Abd Hanifah, in mithill property cases, the prices to be paid should be equivalent to the actual cost of the property at the date of the action for tort. In other kinds of properties, the price should be equal to the price extant at the date of the trespass. ${ }^{40}$

To sum up, it is very plain that the Islamic law principles do not allow any undue influence in any transaction. If any undue influence is practised in a transaction, that performance will be rescinded and the influencer will be bound to restore the money or property to the victim which he took at the time of the transaction.

\section{Conclusion}

In general, a person who has been induced to enter into a transaction by an undue influence, exercised by the defendant or by the third parties, is entitled for a restitution of the money or property which was obtained and retained by the defendant. However, in some cases, the plaintiff cannot prove the loss but the plaintiff can prove that the defendant has exercised an undue influence over him to give something to the defendant.

An affected party has the right to claim a restitution of the money or the property from a transaction which took place under an undue influence in exceptional circumstances, which is recognized as an equitable remedy at present in England and some other common law countries, where the plaintiff is unable to prove the loss on other grounds. ${ }^{41}$ Some scholars argue that an affected party can claim a compensation or damages instead of a restitution for an undue influence in a transaction as stated above. A restitution for an undue influence is sometimes referred to as a quasi-contract as it is not contractual. ${ }^{42}$ Besides, it does not rely on the plaintiff's suffering, loss or damage. Sometimes, the court grants a restitutionary claim, but in most of the cases the court usually refuses to grant a restitution resulting from an undue influence due to the ambiguity of the existing laws. However, according to the Islamic legal principles, the property which was obtained under an undue influence or any other illegal ways in existence, there should be a complete restoration of the actual entity which should be restitutionary by the court's order. If it has been destroyed, the remedial order proceeds to restore the property to the same value and equivalence. Therefore, in case of any undue influence, the plaintiff can claim a restitution of unjust enrichment from the defendant in a transaction and the competent court should give an order for a restitution of the property, instead of a compensation, which is recognised by both the English Law and the Islamic Legal Principles.

\section{References}

[1]. "Al-Quran." (n.d.)

[2]. Andrew Burrows, Ewan Mckendrick, James Edelman. Cases and Materials on the Law of Restitution. New York: Oxford University Press Inc., 2005

[3]. Bant, Elise. "Incapacity, Non Est Factum and Unjust Enrichment." Melbourne University Law Review (2009): 14.

[4]. Birks, Peter. An Introduction to the Law of Restitution. New York: Oxford University Press, 1990.

[5]. Burrows, Andrew A. The Law of Restitution. Oxford : Oxford University Press, 2011.

[6]. Burrows, Andrew. Restatement of the English Law of Unjust Enrichment. Oxford: Oxford University Press, 2013.

[7]. Charless Mitchell, Paul Mitchell. Landmark Cases in the Law of Restitution. Oxford: Hart Publishing, 2006.

[8]. Fong, Cheong May. Civil remedies in Malaysia. Selangor: Sweet \& Maxwell, 2007. 


\section{A Comparative Study of a Restitutionary Remedy for an Undue Influence between the English Law}

[9]. Jaffey, Peter. The Nature and Scope of Restitution. Oregon: Hart Publishing, 2000.

[10]. Mei Pheng Lee, Ivan Jeron Detta. Business law. Shah Alam: Oxford Fajar Sdn. Bhd., 2009.

[11]. Sabahi, Borzu. Compensation and Restitution in Investor-State Arbitration: Principles and Practice. Oxford: Oxford University Press, 2011.

[12]. Saiman, Chain. "Restitution in America: Why the US Refuse to Join the Global Restitution Party." Oxford Journal of Legal Studies 28.1 (2008): 99-126.s

[13]. Virgo, Graham. The Principles of the Law of Restitution. Oxford: Oxford University Press, 2006.

[14]. Weaver, David F. Partlett and Russell L. "Restitution: Ancient Wisdom." Loyola of Los Angeles Law Review 36 (2003): $975-989$.

\section{List of Cases}

[15]. Allcard v. Skinner (1887) 36 CHD 245 CA

[16]. Bank of Credit \& Commerce International SA (BCCI) v. Aboody [1990] 1QB 923

[17]. CIBC Mortgages plc v. Pitt [1994] 1AC 200

[18]. Credit Lyonnais Bank Netherland NVv. Burch [1997] 1 All ER 144

[19]. Elliot \& Anor v. Stamp \& Anor [2006] IEHC 336

[20]. Fry v. Lane (1888) LR 40 Ch D 312 Ch D

[21]. Geoffrey Herbert Thomas Randall v. Philip Willium Charles Randall [2004] EWHC 2258

[22]. Jayne Hewett v. First Plus Financial Group Plc [2010] EWCA Civ 312

[23]. John Wadlow v. Henry Olusegun Adeola Samuel [2006] EWHC 1492 (QB)

[24]. Khalid Ali Ismail Turky v. Adnan Mohammed Awadh \& Other [2005] EWCA Civ 382

[25]. Kleeinworth Benson Ltd v Lincoln City Council [1999] 2 AC 349

[26]. Lipkin Gorman v Karpnale Ltd [1991] 2 AC 548

[27]. Maureen Mary Leeder v. Denis Michael Stevens [2005] EWCA Civ 50

[28]. Maureen Niersmans v. Bernard Pesticcio [2004] WECA Civ 372

[29]. Mrs Joyce De Wind v. Mr Colin Wedge [2008] EWHC 514 (ch)

[30]. National Commercial Bank (Jamaika) Ltd v. Hew [2003] UKPC 51 PC

[31]. Nicholas Geoffrey Daniel v. Mrs Irene Margaret Drew [2005] EWCA Civ 507

[32]. $\quad R$ v. Attorney General for England \& Wales [2003] UKPC 22; [2003] EMLR 24

[33]. Royal Bank of Scotland v. Etridge (No 2) [2001] 2 AC 773

[34]. Samuel (Professionally known as Seal) v. Wadlaw [2007] EWCA Civ 155

[35]. See Hua Realty Berhad v KTS News Sdn. Bhd [2009] 1 LNS 64

[36]. UCB Group Ltd v. Mrs Gillian Hedworth [2003] EWCA Civ 1717 (Ch)

[37]. Woolwish Equitable Building Society v IRC [1993] AC 70

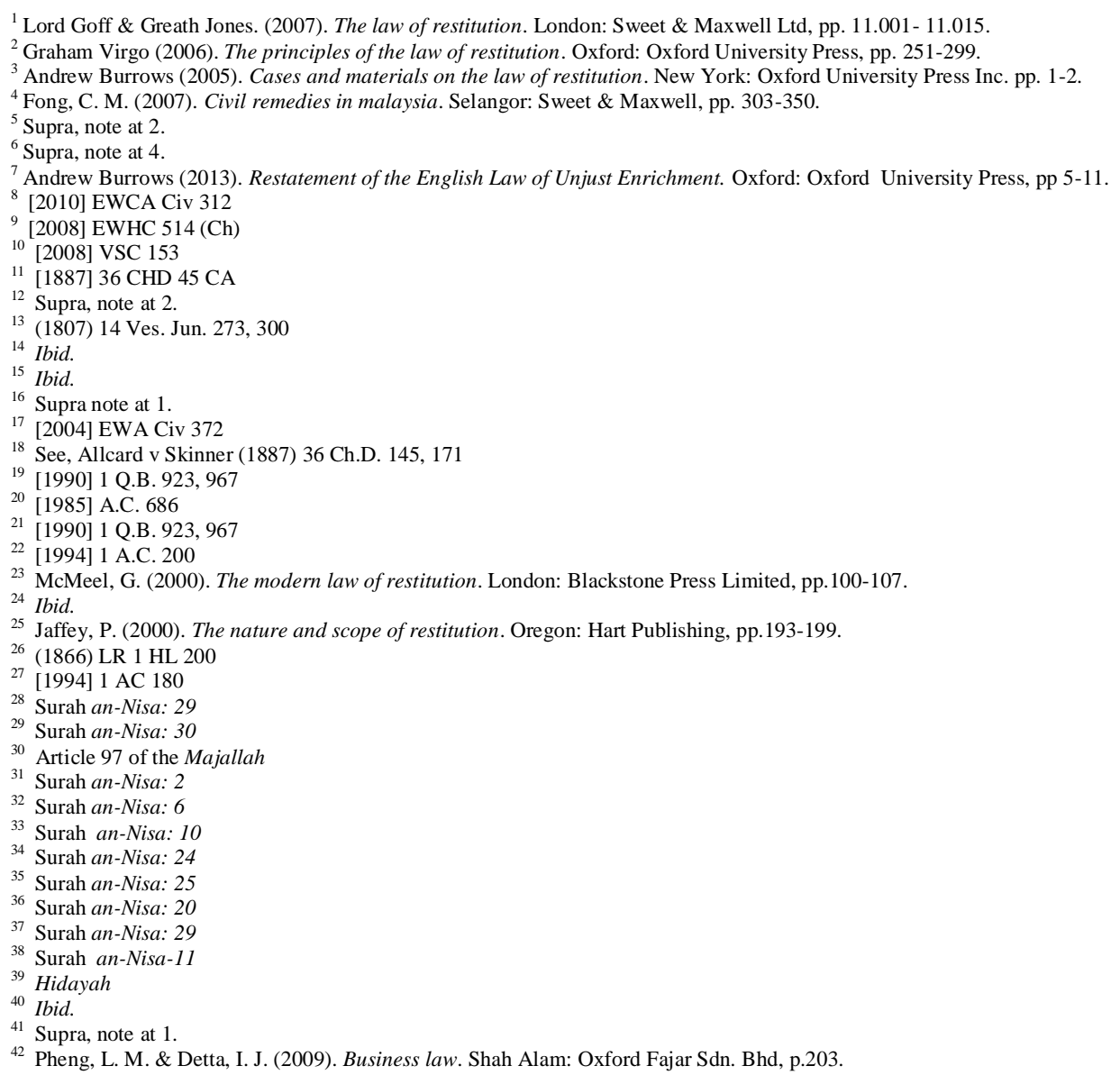

